\title{
Solicitation of Patient Consent for Bilateral Orchiectomy in Male Canids: Time to Rethink the Obligatory Paradigm
}

\author{
Alice Wünderlandt ${ }^{1 *}$, Olivia Doll ${ }^{2}$ and Gal Usalida ${ }^{3}$ \\ ${ }^{1}$ Lutenblag University, Molvania \\ ${ }^{2}$ Subiaco College of Veterinary Science, Australia \\ ${ }^{3}$ Avicephalon Atmospheric Risk Assessment Center, USA \\ *Corresponding author: Alice Wünderlandt, Lutenblag University, Molvania
}

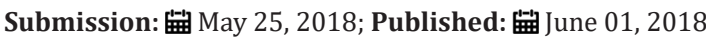

\section{Opinion}

Male canid subjects residing in a human domestic environment are routinely subject to bilateral orchiectomy, effected primarily in order to preclude reproduction and to suppress undesirable behavioral traits, including agonism and inappropriate urine dissemination [1]. This practice has remained constant and routine for decades (if not centuries), and is widely conducted globally despite evidence of deleterious secondary effects; these include (among others) increased prevalence of injury to the anterior cruciate ligament [2], higher risk of prostatic carcinoma [3], and a miscellaneous suite of behavioral mal adaptations [4-6]. In addition, post-traumatic stress, often combined with diminished self-esteem, may be manifest in the subject as an acute or chronic complication of the operation, with an effective duration of weeks to years (Wünderlandt and Borzoi, unpublished data). Furthermore and most importantly within the context of this note the procedure is almost invariably performed without the patient's informed consent.

We suggest it is time to propose an altered paradigm within a hyper-ethical contextual framework, in which input and consent is solicited from the subject in question prior to surgical intervention. This would be in keeping with an evolving, and increasingly enlightened and progressive, bioethical framework, at least within Western society [7]. It also parallels recent ethical developments within the emerging field of consensual paediatrics [8].

Whilst highly defensible in a scientific, ethical and legal context, the principal obstacle to implementation of this novel bioethical approach remains the current absence of a mutually comprehensible inter specific linguistic system. Nonetheless, this problem may be resolvable in one of two ways.

First, application of a robustly structured program of operant conditioning would involve training to express positive or negative vocal responses to a variety of commonly encountered stimuli;

once the subject has been so trained to reliably opine, consent or rejection could be determined through exposure to videographic representation of the procedure. The alternative approach to consent would involve parapsychological channeling. While appealing due to its inherent simplicity, this approach has yet to be subjected to double-blind experimentation and statistical analysis of results, though it should not be difficult to conduct such research providing a statistically robust sample set of sufficiently self-deluded bedlamites can be assembled within a controlled laboratory environment.

However this is achieved, we would argue that prompt action towards this goal is essential. In a world of increasing awareness of individual needs and heightened ethical sensitivities, the time to permit gonadal self-determination by our most stead fast quadrupedal associates is long overdue.

\section{References}

1. Stubbs WP, Bloomberg MS, Scruggs SL, Shille VT (1991) Gonadectomy in immature dogs: effects on skeletal, physical, and behavioral development. J Am Vet Med Assoc 198(7): 1198-1203.

2. Slauterbeck JR, Pankratz K, Xu KT, Bozeman SC, Hardy DM (2004) Canine ovariohysterectomy and orchiectomy increases the prevalence of ACL injury. Clin Orthop Relat Res 429: 301-305.

3. Teske E, Naan EC, Van Dijk EM, Van Garderen E, Schalken JA (2002) Canine prostate carcinoma: epidemiological evidence of an increased risk in castrated dogs. Mol Cell Endocrinol 197(1-2): 251-255.

4. Salmeri KR, Bloomberg, MS, Scruggs SL, Shille V (1991) Gonadectomy in immature dogs: effects on skeletal, physical, and behavioral development. J AmVet Med Assoc 198(7): 1193-1203.

5. Maarschalkerweerd RJ, Endenburg N, Kirpensteijn J, Knol BW (1997) Influence of orchiectomy on canine behaviour. Vet Record 140(24): 617619.

6. Neilson JC, Eckstein RA, Hart BL (1997) Effects of castration on problem behaviours in male dogs with reference to age and duration of behaviour. J Am Vet Med Assoc 211(2): 180-182. 
7. Acampora RR(2006) Corporal compassion: animal ethics and philosophy of body. University of Pittsburgh Press, Pittsburgh, Pennsylvania, USA, p. 201.
8. Anon (1995) Informed consent, parental permission, and assent in pediatric practice. American Academy of Pediatrics. Committee on Bioethics Pediatrics 119(2): 405.

\section{For possible submissions Click Here Submit Article}

Creative Commons Attribution 4.0

International License

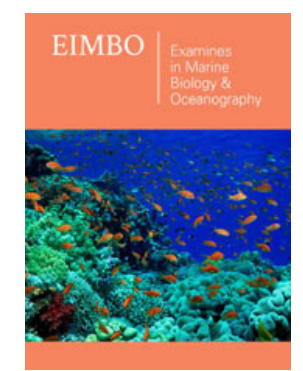

Examines in Marine Biology \& Oceanography Benefits of Publishing with us

- High-level peer review and editorial services

- Freely accessible online immediately upon publication

- Authors retain the copyright to their work

- Licensing it under a Creative Commons license

- Visibility through different online platforms 